\title{
数値モデルを用いた開水路チェックゲートの機能評価
}

一のI : 間接型フロート式上流水位一定グートの場合-

\author{
稲垣仁根 ${ }^{1} \cdot$ 益田和範 ${ }^{2} \cdot$ 小西邦寿 ${ }^{3} \cdot$ 大塚明克 $^{3} \cdot$ 小倉尚基 ${ }^{4} \cdot$ 秋吉康弘 $^{5}$
}

\section{Performance Evaluation of Check Gate in Canal Using a Numerical Model}

-PART I: Float-Operated Constant Upstream Level Control Gate in Indirect Level Action-

\author{
Hitone Inagaki ${ }^{1}$, Kazunori Masuda ${ }^{2}$, Kunihisa Konishi ${ }^{3}$, Akiyoshi Ootuka $^{3}$ \\ Naoki Ogura ${ }^{4}$ and Yasuhiro Akiyoshi ${ }^{5}$
}

\begin{abstract}
Float-operated water level control gates in direct level action (say, Neyrtec-design gates) are successfully used as hydro-mechanically controlled cross regulators in many canal systems in the world. The Japanese experiences learned from their use in the Aichi Water Supply System and the Toyogawa Water Supply System, however, show that a series of the gates in direct level action on relatively short successive reaches of the canal with the bed slope of $1 / 2000$ to $1 / 5000$ often creates interference water surface oscillations which result in high frequency hunting, and the gate located closely upstream of a siphon conduit is prone to be unstably controlled depending on the flow in the conduit. In this paper, as the alternative to the conventional Neyrtec-design gates, use of the particularly designed gate that may successfully be controlled in difficult conditions encountered in Japan is proposed. The float that is installed in an off-canal chamber automatically operates the upstream level control gate in the manner of indirect level action. Performance and validity of the gate in the Aichi Water Supply System are evaluated by the numerical investigations together with the in-situ hydraulic tests. The results show that the off-canal float could stably operate the gate to implement constant upstream water level control, confining upstream water level fluctuations within a desired range. In addition, it is demonstrated that the numerical model in which mechanical action of the gate is also incorporated is capable of successfully reproducing the canal flow and the gate action.
\end{abstract}

Keywords: Check gate; Open channal; Mathematical model; Constant upstream level control gate; Floattype

\section{1 はじめに}

開水路の水位を確保する自動水位調節ゲートとして は，フランス・ネルテック社製のゲート群が広く世界 で使用され，信頼性の高い自動式ゲートとして認知さ れている.ゲートの種類としては，上流水位を一定に 制御するアミルゲートと下流水位を一定に制御するア ビスゲート，アビオゲートがあり，国内では愛知用水 や豊川用水において導入され，唯一の無動力で稼働す る自動水位調節ゲートとして農業用水路に普及してき た（農林水産省，2001a）。これらのゲートは，屝体に フロートが内蔵されていることに特徴があり，フロー ト内蔵型の自操型ゲートに分類され，さらに制御対象 となる上下流の水面がフロートに直接接触して動作す

\footnotetext{
1宮崎大学農学部助教授 Associate Professor, Faculty of Agriculture, Miyazaki University, 1-1 Gakuen Kibanadai-nishi, Miyazaki-shi, Miyazaki, 889-2192 Japan

2水資源開発公団愛知用水総合事業部部長 General Manager, United Division of Aichi Waterworks, Water Resources Development Public Corporation, 373 Akaike Yasita, Nitushinn-shi, Aichi, 470-0126 Japan

3水資源開発公団愛知用水総合事業部課長 Manager, United Division of Aichi Waterworks, Water Resources Development Public Corporation, 373 Akaike Yasita, Nitushinn-shi, Aichi, 470-0126 Japan

4 豊国工.業課長 Manager, HOKOKU KOGYO CO., LTD, 6400-3 Misonou Saijo-cho, Higashi-Hiroshima-shi, Hiroshima, 739-0024 Japan

5 宮崎大学農学部教授 Professor, Faculty of Agriculture, Miyazaki University, 1-1 Gakuen Kibanadai-nishi, Miyazakishi, Miyazaki, 889-2192 Japan
}

ることから, Direct Level Action 型のフロート式ゲー トに分類できる.

愛知用水は, 供給主導型の水路であるため, 主に上 流水位を一定にするアミルゲートを使用しているが, 水路勾配が 1/2000〜1/5000 と急であるため，ゲート 間の距離が短くなり, さらに, 地形が複雑なためサイ ホンやトンネルが数多く混在するという特徵がある. ゲート間の距離が短い場合は前後のグート相互に干 渉が生じる可能性があり，またゲートの下流にサイホ ンがある場合は, サイホン内の流れが安定しないと， ゲートの下流水面が乱れてグートがハンチングを生 じるなどの課題を抱えていた.これらの課題は, 国内 の農業用水路におけるゲートの設置条件やその水理環 境に起因するものであるが，管理の現場ではゲートの アームにオイルダンパを設置するなど対策を講じて現 在に至っている.

その後，フロートを水路外に設置した間接型フロー 卜式の上流水位一定ゲートが国内で開発され（農林水 産省，2001b），九州地区などで採用されたことから， 愛知用水の二期事業でも, このゲートを採用候補とし た.このゲートは, 制御対象となる上流水位とフロー 卜の間に欠口を有する隔壁を設置するため, Indirect Level Action 型のフロート式ゲートに属するといえる. このゲートの特徵としては, フロート室は水路と欠口 で連通しているため開水路の水面変動の影響が緩和さ れること，設定する上流水位を任意に変更できること， ゲート断面が水路断面と同じ矩形であることなど国内 の実状に考慮した機能が付加されている. 
そこで，本ゲートの制御機能について検討した結果， 愛知用水で採用することとし，上流部では既に設置済 みで稼働中である。また，下流部におうける農業用水専 用区間でのゲートの連続設置などの様々な水路システ ムの課題を検討するために，ゲートの数值モデルの開 発とシミュレーション手法の整備に着手し, 現地実験 の結果をほぼ再現できるところまで成果を得た。

本論文では，間接型フロート式上流水位一定ゲー トの現地水理実験の結果と数值モデルを用いたシミュ レーションによる再現結果との比較を行い，ゲートの 制御機能の評価を行った。

\section{2 フロート式上流水位一定ゲートの分類と特徴} 愛知用水では二期事業以前は直接型フロート式上流水 位一定グートのアミルゲートが主に使われていた。こ の直接型フロート式ゲートは，屝体とフロートが一体 となっており, フロートに作用する浮力, ゲート自重, カウンターウエイトによるモーメントの釣り合いで動 作する仕組みになっている.

そのため, 開水路の水面がフロートに直接接触する ことにより，フロートの浮力が増減してゲートが駆動 されるので, 愛知用水のようにゲート下流にサイホン があり流況が安定しない場合には，ゲートの動作が影 響を受けることになる。また，実際の水管理において はゲートの設定水位の状況に応じた変更が必要となる 場合が生じるが，設定水位は変更できず，制御精度も 土 $10 \mathrm{~cm}$ と粗いので細かな水位管理には支障が生じる 場合がある。ささらに二期事業では水路断面が台形から 矩形に変更され，水路両側のバームが管理用道路とし て使用されるため，ゲートも矩形断面であることが望 まれた。

二期事業では上記のような国内の使用条件を考慮し て，フロートを設置する水槽と開水路を欠口で連通し 水面変動の影響を緩和できる, 設定する上流水位を任 意に変更できる，ゲート断面が水路断面と同じ矩形で あるなどの特徴を有する間接型フロート式の上流水位 一定ゲートが採用されることとなった．アミルゲート の概要を図 1 に，間接型フロート式の上流水位一定 ゲートの概要を図 2 に，さらに直接・間接型のフロー 卜式上流水位一定ゲートの比較を表 1 に示す.

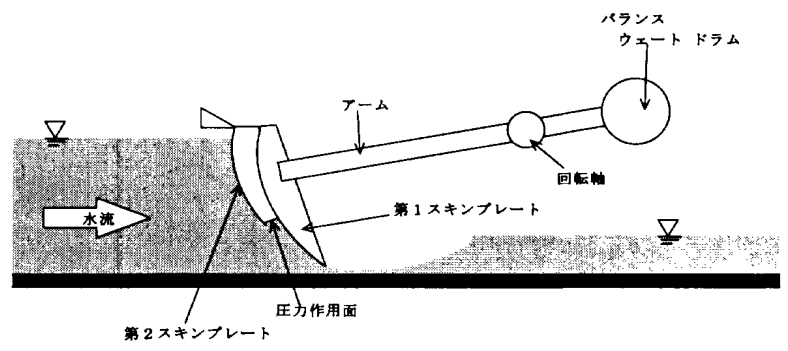

図 1: アミルゲートの概要

3 間接型フロート式上流水位一定ゲートの作動機構 間接型フロート式上流水位一定ゲートは，ゲートの駆 動機構を水路の外に設置していることに構造的な特徵 がある. 水路の外部側面に 3 個の連続した水槽 $\mathrm{A}$, フ ロート室, 水槽 $\mathrm{B}$ を設置し, 上流側の水槽 $\mathrm{A}$ と下流側

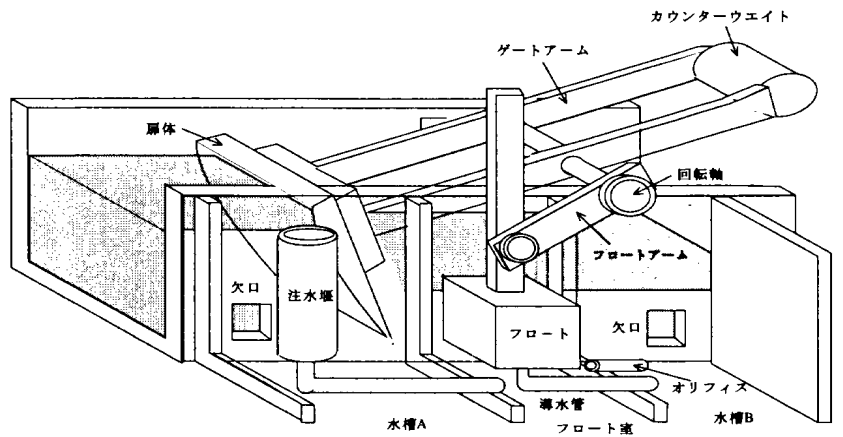

図 2: 間接型フロート式上流水位一定ゲートの概要

の水槽 B は水路と欠口により接続しており流水が自 由に出入りでき, 水槽 $\mathrm{A}$ はゲートの上流水位, 水槽 $\mathrm{B}$ は下流水位と同じとなる. 水槽 $\mathrm{A}, \mathrm{B}$ は水路と欠口を 介して接続しているため, 水路の波立ち等の影響を受 けにくくなっている.

作動の原理は表 2 の間接型フロート式ゲートの作動 フロー表と図 3 の間接型フロート式上流水位一定ゲー トの作動機構図に示す.

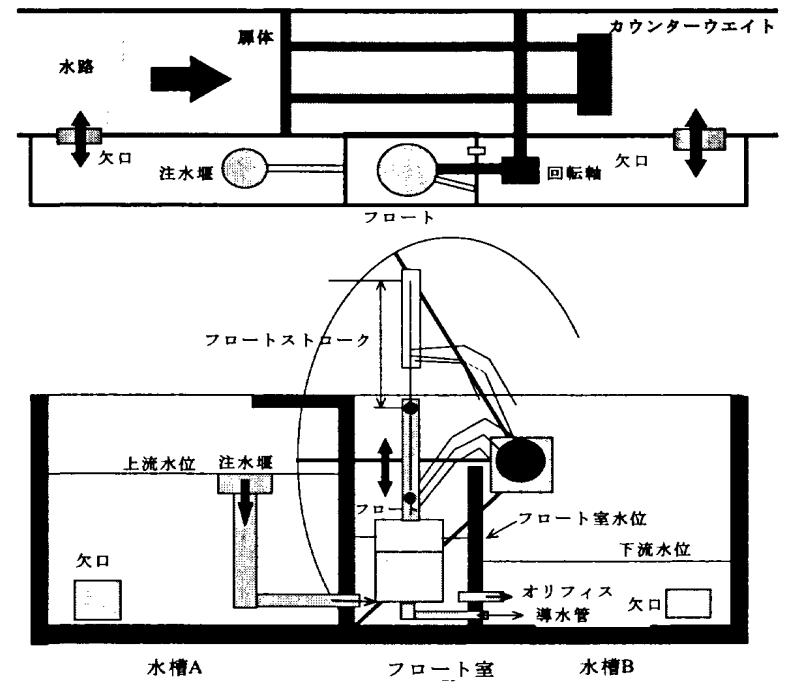

図 3: 間接型フロート式上流水位ゲートの作動機構図

4 間接型フロート・ゲートの作動機構の運動方程式

\section{1 既往のゲートモデル}

自動水位調節ゲートを開水路の数理モデルに組み込ん で解析した事例は, 白石ら (1972) による研究がある が，白石らは「上流一定ゲートは上流水位を常に設定 水位に維持するように作動するのであるから，ゲート とゲート直上流の任意区間の流量の連続条件が保持さ れるように, ゲート流量を設定するという方法」を採 用している。

白石らの手法は, 自動水位調節ゲートを含んだ水路 システムの流況を再現するために，ゲートが正常に作 動した場合に生じる結果を水路モデルに組み込んだも のである. 従って, ゲート自体の作動機構をモデル化 
表 1: フロート式ゲートの機能比較表

\begin{tabular}{|c|c|c|}
\hline 項 目 & $\begin{array}{c}\text { 間接型 } \\
\text { Indirect Level Action 型 }\end{array}$ & $\begin{array}{c}\text { 直接型 } \\
\text { Direct Level Action 型 }\end{array}$ \\
\hline 動 力 & 水路外に設置したフロート & ゲート扉体に内蔵したフロート \\
\hline 駆動方式 & $\begin{array}{l}\text { フロートに作用する浮力, ゲート自重, } \\
\text { のモーメントの釣り合い }\end{array}$ & カウンターウエイトによる回転軸周り \\
\hline フロート位置 & $\begin{array}{l}\text { 水路外にフロート水槽を設置し，欠口 } \\
\text { で連通する }\end{array}$ & 水路内のゲート扉体に内蔵する \\
\hline フロート内への水の導入 & 水を導入する & 水を導入しない \\
\hline 上流設定水位の精度 & $\pm 3.0 \mathrm{~cm}$ 以内 & $\pm 10.0 \mathrm{~cm}$ 程度 \\
\hline 上流設定水位の変更 & 可能 & 不可能 \\
\hline 変動流量対する機能性 & $\begin{array}{l}\text { 流量ゼロから計画流量の範囲で任意な } \\
\text { 流量に対して作動する }\end{array}$ & $\begin{array}{l}\text { 計画流量の約半分以下の流量では十分 } \\
\text { に作動しない }\end{array}$ \\
\hline 水路断面形状 & 矩 形 & 台 形 \\
\hline 上流水位一定ゲートの例 & ウオッチマンゲート & アミルゲート \\
\hline 下流水位一定ゲートの例 & フローマンゲート & アビスゲート, アビオゲート \\
\hline
\end{tabular}

したのではなく，ゲート自体の作動機構の評価を行う には限界があった。そこで，間接型フロート式上流水 位一定ゲートを開水路の数理モデルに組み込むために， ゲートの作動機構の数值モデル化を行う.

\section{2 フロート室流入量}

フロート室への流入量 $Q_{i}$ は，注水堰からの越流量で 与えられるため, (1) 式で与えられる.

$$
Q_{i}=C_{i} \pi D_{i}\left(H_{u}-H_{s}\right)^{3 / 2}
$$

ここで, $H_{u}=$ 水槽 $\mathrm{A}($ ゲート直上流 $)$ の水深 $(\mathrm{m}), H_{s}$ $=$ 注水堰の堰頂の高さ $(\mathrm{m}), D_{i}=$ 注水堰の直径 $(\mathrm{m})$, $C_{i}=$ 堰の流量係数 $(=1.8), Q_{i}=$ フロート室流入量 $\left(\mathrm{m}^{3} / \mathrm{s}\right)$ である.ただし, $H_{u} \leq H_{s}$ の時は, $Q_{i}=0$ で ある。

\section{3 フロート室流出量}

フロート室からの流出量 $Q_{0}$ は, フロート室と下流水 槽 B の水深の差によるオリフィス流出となるため, (2) 式で与えられる。

$$
Q_{o}=C_{o} \frac{\pi D_{o}^{2}}{4} \sqrt{2 g\left(H_{f}-H_{l}\right)}
$$

ここで, $H_{f}=$ フロート室の水深 $(\mathrm{m}), H_{l}=$ 水槽 $\mathrm{B}$ (ゲート直下流 $)$ の水深 $(\mathrm{m}), D_{o}=$ オリフィスの直 径 $(\mathrm{m}), C_{o}=$ オリフィスの流量係数 $(=0.6), Q_{o}=$ フロート室流出量 $\left(\mathrm{m}^{3} / \mathrm{s}\right)$ である.ただし， $H_{f} \leq H_{l}$ の時は， $Q_{o} \leq 0$ である.

\section{4 フロート内流入出量}

フロートの昇降動作はフロートの内外水位差に追従す るが，定常状態ではフロート内水面の位置は水槽 B の 水深 $H_{l}$ に一致し, フロート室水深 $H_{f}$ と喫水差 $H_{d}$ を保持して均衡している。この均衡状態から $H_{f}$ が変 化した場合のフロート内への流入出量 $Q_{f}$ は, (3) 式 で与えられる.

$$
Q_{f}=C_{f} \frac{\pi D_{f}^{2}}{4} \sqrt{2 g\left(H_{f}-H_{d}-H_{l}\right)}
$$

ここで, $H_{d}=$ フロートの喫水差 $(\mathrm{m}), D_{f}=$ 導水管 の直径 $(\mathrm{m}), C_{f}=$ 導水管の流量係数 $(=0.5), Q_{f}=$ フロート室内流入出量 $\left(\mathrm{m}^{3} / \mathrm{s}\right)$ である. ただし, $H_{f}$ $H_{d} \leq H_{l}$ の時は, $Q_{f} \leq 0$ である.

\section{5 フロート室の連続方程式}

フロート内外の水深の関係は, 定常状態では (4) 式で 与えられる。

$$
H_{f 1}=H_{f}-\left(H_{w}+H_{d}\right)
$$

ここで, $H_{f 1}=$ フロート底面から水路底までの水深 (m), $H_{w}=$ フロート内の水深 $(\mathrm{m})$ である.

水深の時間的な変動がある場合は, $H_{f 1}$ は (4) 式を $t$ で微分して (5) 式で与えられる. なお, 喫水差 $H_{d}$ は 水深の変化により変動しないものと考える.

$$
\frac{d H_{f 1}}{d t}=\frac{d H_{f}}{d t}-\frac{d H_{w}}{d t}
$$

フロート室内の連続方程式は, 微小時間 $d t$ のフロー 卜室水深の変動量 $d H_{f}$, フロートの微小変動量 $d H_{f 1}$, フロート室の水の流入量 $Q_{i}$ および流出量 $Q_{o}$ を用い て, (6) 式で与えられる.

$$
\left(A_{f}-A_{f 1}\right) \frac{d H_{f}}{d t}+A_{f 1} \frac{d H_{f 1}}{d t}=Q_{i}-Q_{o}
$$

ここで, $A_{f}=$ フロート室の面積 $\left(\mathrm{m}^{2}\right), A_{f 1}=$ フロー トの面積 $\left(\mathrm{m}^{2}\right)$ である.

(5) 式を(6) 式に代入して整理すると (7) 式が得ら れる。

$$
A_{f} \frac{d H_{f}}{d t}-A_{f 1} \frac{d H_{w}}{d t}=Q_{i}-Q_{o}
$$

フロート内の水位変化を表す $(9)$ 式を (7) 式に代入し て整理すると, フロート室の連続方程式として (8) 式 が得られる。

$$
A_{f} \frac{d H_{f}}{d t}=Q_{i}-Q_{o}+Q_{f}
$$


表 2: 間接型フロート式ゲートの作動フロー表

\begin{tabular}{|c|c|}
\hline 項 目 & 作動の内容 \\
\hline 水槽 $\mathrm{A}$ & $\begin{array}{l}\text { 開水路の水位が上昇すると, 流入口からの流入量が発生し, 水槽 } \mathrm{A} \\
\text { の水位が上昇する. }\end{array}$ \\
\hline 注水堰 & $\begin{array}{l}\text { 開水路の上流水位が上昇し, 注水堰の位置より高くなるとフロート } \\
\text { 室への流入量が発生する.この注水堰の高さが上流制御水位であり, } \\
\text { この高さを変化させて, 設定水位を容易に変更することができる. }\end{array}$ \\
\hline フロート室 & $\begin{array}{l}\text { フロート室への流入量が増減するとフロート室の水位が変化し, フ } \\
\text { ロートが上下動する. }\end{array}$ \\
\hline 水槽 B & $\begin{array}{l}\text { フロート室の水位と下流水位の差により, フロート室からオリフィ } \\
\text { スを経由して水を水槽 } \mathrm{B} \text { 人流出させる. }\end{array}$ \\
\hline フロートアーム & $\begin{array}{l}\text { フロート上部に設置されたフロートアームは回転軸に接続しており、 } \\
\text { フロートの上下運動がゲートの回転運動へと変換され，ゲートの扉 } \\
\text { 体の開閉を行う. }\end{array}$ \\
\hline フロート内部 & $\begin{array}{l}\text { フロートの上下運動が急激に起こらないようにフロート内部にフロー } \\
\text { ト導水管を接続して, 導水管から下流水位に対応した量の水の出入 } \\
\text { りがある構造になっている. }\end{array}$ \\
\hline カウンターウェイト & $\begin{array}{l}\text { フロートの上下運動だけでは、重い金属製のゲートを開閉するのが } \\
\text { 困難であるので， ウエイトを付している. }\end{array}$ \\
\hline
\end{tabular}

\section{6 フロート内の連続方程式}

フロート内の水深 $H_{w}$ は，フロートの昇降動作と連動 するが，フロート内は水槽 $\mathrm{B}$ と導水管で連通している ので, フロート内水深は水槽 $\mathrm{B}$ の水深 $H_{l}$ に一致する ベく変動する. 従って, フロート内の連続方程式は, 微小時間 $d t$ のフロート内水深の変動量 $d H_{w}$, フロー ト内からの水の流入出量 $Q_{f}$ を用いて，(9) 式で与え られる。

$$
A_{f 1} \frac{d H_{w}}{d t}=Q_{f}
$$

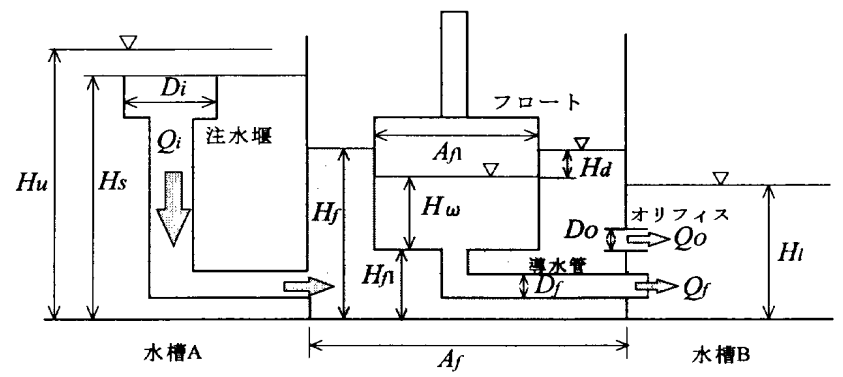

図 4: 間接型フロート式上流水位ゲートの作動機構図

\section{7 フロートアームの角度}

ゲートの開度が $H_{g}$ となる場合のゲートアーム, フロー トアーム及びフロートの位置関係は図 5 の太線で示す ようになっている. 図5の細線は, ゲートが全閉した 場合のアームとフロートの位置関係を示している.

そこで, フロートアームの任意の開度 $\theta$ とフロート の位置 $H_{f 1}$ の関係は，(10) 式により与えられる．な お，フロートの位置 $H_{f 1}$ は，(8) 式で求めたフロート 室水深 $H_{f},(9)$ 式で求めたフロート内水深 $H_{w}$ と喫
水差 $H_{d}$ を用いて，(4) 式より求める.

$$
\frac{H_{f 1}-H_{f c}}{R_{f}}=\sin \theta_{f}-\sin \left(\theta_{f}-\theta\right)
$$

さらに，(10) 式を整理して，フロートアームの任意の 角度 $\theta$ は (11) 式で与えられる.

$$
\theta=\theta_{f}-\sin ^{-1}\left(\sin \theta_{f}-\frac{H_{f 1}-H_{f c}}{R_{f}}\right)
$$

ここで, $R_{f}=$ フロートアーム長 $(\mathrm{m}), H_{f c}=$ ゲート 全閉時のフロートの底面から水路底までの水深 $(\mathrm{m})$, $\theta=$ フロートの底面から水路底までの水深が $H_{f 1}$ の時 にフロートアームが全閉時のフロートアームとなす角 度 $(\mathrm{rad}), \theta_{f}=$ ゲート全閉時のフロートアームが水平 面となす角度 $(\mathrm{rad}), \theta_{g}=$ ゲート全閉時のゲートアー ムが水平面となす角度 $(\mathrm{rad})$ である.

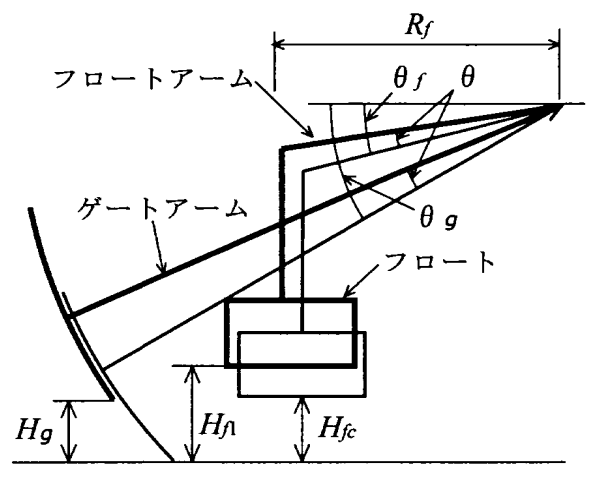

図 5: フロートアームとフロートの位置関係図

\section{8 ゲートの開度}

ゲートアームとフロートアームは常に一定の角度 $\theta_{g}-$ $\theta_{f}$ を保つように結合されているので, フロートアーム 
が角度 $\theta$ だけ回転した場合は, ゲートアームも角度 $\theta$ だけ回転する.ゲートの開度が $H_{g}$ となる場合のゲー トアームと扉体の位置関係は図 6 の太線で示すように なっている. 図 6 の細線は, ゲートが全閉した場合の アームと扉体の位置関係を示している.

従って, フロート・ゲートアームが角度 $\theta$ だけ回転 した場合のゲートの開度 $H_{g}$ は (12) 式で与えられる.

$$
H_{g}=R_{g} \sin \theta_{g}-R_{g} \sin \left(\theta_{g}-\theta\right)
$$

ここで, $R_{g}=$ ゲートアーム長 $(\mathrm{m}), \theta=$ フロートアー ムの回転角 $(\mathrm{rad}), \theta_{g}=$ ゲート全閉時のゲートアーム が水平面となす角度 $(\mathrm{rad}), H_{g}=$ ゲートの開度 $(\mathrm{m})$ である。

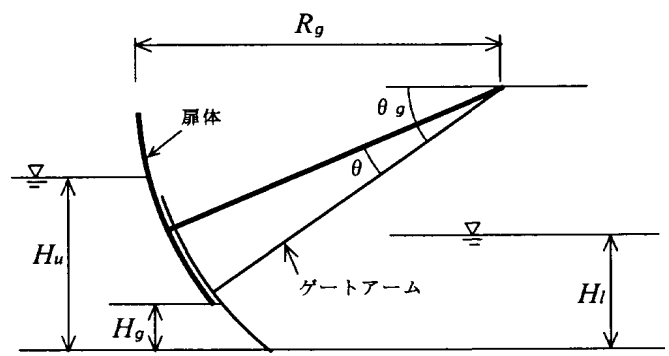

図 6: ゲートアームとゲート開度

\section{9 ゲートの流量}

ゲートの流量は, Henryによるスルースゲートについ ての流量係数（土木学会，1971） $C_{1}$ を用いて，(13) 式で与えられる.

$$
Q_{g}=C_{1} H_{g} B \sqrt{2 g H_{u}}
$$

ここで, $B=$ 流出幅 $(\mathrm{m})$ である.

ゲートの開度 $H_{g}$ を用いて, ゲート上下流の水深を, $H_{u}=\alpha H_{g}, H_{l}=\beta H_{g}$ と設定すると, ゲートの流量 は(14) 式で得られる.

$$
\begin{aligned}
Q_{g} & =C H_{g} B \sqrt{2 g\left(H_{u}-H_{l}\right)} \\
& =C \sqrt{1-\frac{\beta}{\alpha}} H_{g} B \sqrt{2 g H_{u}}
\end{aligned}
$$

ここで， $C=$ ゲートの上下流水位差を用いた場合の 流量係数である.

流量係数 $C$ と $C_{1}$ の関係は, (15) 式で与えられるの で, $C_{1}$ と $\alpha, \beta$ の関係を $C$ との関係に変換して, 図 7 に示す流量係数 $C$ を求めた.

$$
C=C_{1} \sqrt{\frac{\alpha}{\alpha-\beta}}
$$

\section{5 シミュレーション手法}

\section{1 開水路流れの解析手法}

開水路の 1 次元の不定流について，摩擦損失にマニ ング則を適用した場合の運動方程式と連続方程式は, (16) 式と (17) 式で表すことができる.

$$
\frac{1}{g} \frac{\partial u}{\partial t}+\frac{1}{g} \frac{\partial}{\partial x}\left(\frac{u^{2}}{2}\right)+\frac{\partial H}{\partial x}+i+\frac{n^{2} u|u|}{R^{4 / 3}}=0
$$

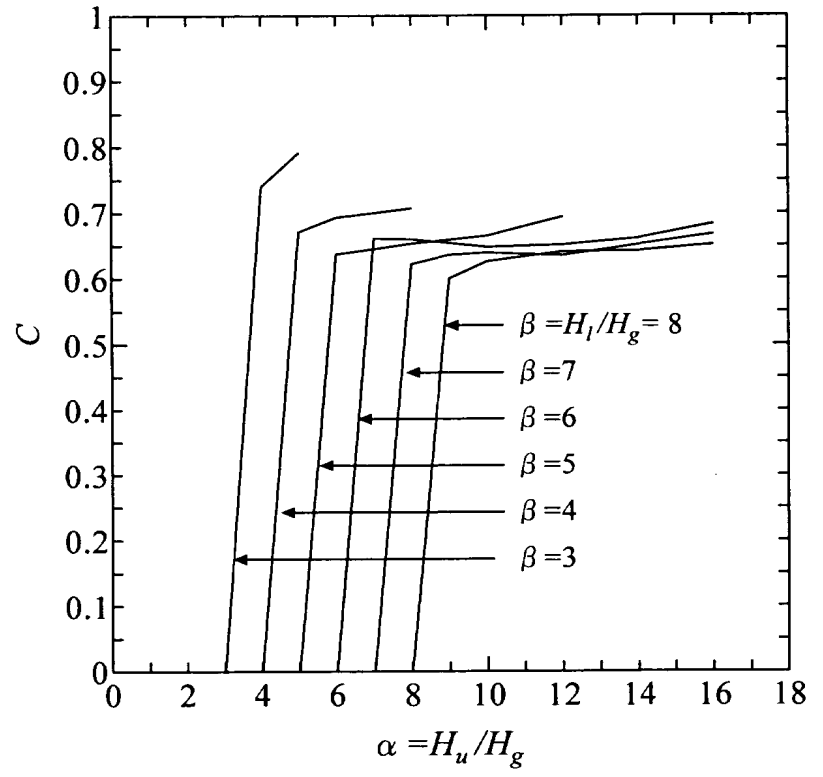

図 7: ゲートの流量係数

$$
\frac{\partial A}{\partial t}+\frac{\partial Q}{\partial x}=q
$$

ここに, $g=$ 重力の加速度 $\left(9.8 \mathrm{~m} / \mathrm{s}^{2}\right), u=$ 流速 $(\mathrm{m} / \mathrm{s})$, $x=$ 距離 $(\mathrm{m}), H=$ 水深 $(\mathrm{m}), t=$ 時間 $(\mathrm{s}), n=$ 粗 度係数 $\left(\mathrm{m}^{-1 / 3} \mathrm{~s}\right), R=$ 径深 $(\mathrm{m}), A=$ 流積 $\left(\mathrm{m}^{2}\right), Q$ $=$ 流量 $\left(\mathrm{m}^{3} / \mathrm{s}\right), i=$ 水路底勾配である.

(16)，(17) 式を中心差分スキーム (白石英彦，1969) で差分化して，流速と水深を求める.

\section{2 フローチャート}

チェックゲートのフロートの作動機構の運動方程式は 4 次のルンゲ・クッタ法による数值積分を用いて解き, 時間 $t$ のフロート室の水深 $H_{f}$ とフロート内の水深 $H_{w}$ を求める.この水深を用いて, フロートアームの回転 角 $\theta$, ゲートの開度 $H_{g}$ を求め, ゲート流量 $Q_{g}$ を算 出する。

開水路流の運動・連続方程式を中心差分スキーム で解く過程において, ルンゲ・クッタ法を用いてフ ロートの運動方程式を解く部分の組み込みについて, FORTRAN 言語に準じたフローチャートを図 8 に示 す.ここで， $\mathrm{m}$ はモデル数，jstop は最大時間ステッ プ数を示す.

\section{6 現地水理実験による機能検討}

\section{1 実験水路の概要}

現地水理実験を行ったゲートは，八幡チェックであり， このゲートは愛知用水の上工用水と農業用水の共用区 間の愛知池と佐布里池に挟まれた区間の末端に位置す る.この区間の水路勾配は $1 / 5000$ と緩やかである.

八幡チェックと上流の開水路の概要を写真 1,2 に 示寸. 開水路は, 幅 $3.50 \mathrm{~m}$, 高さ $2.40 \mathrm{~m}$ の 2 連の矩形 水路であるが，水路の中央には計画水位の場合に溺れ る高さの隔壁が設置されている.八幡チェックの直上 流には東浦揚水機場が設置されており，揚水機場のポ ンプと八幡チェックゲートの諸元を表 3 に示す. 


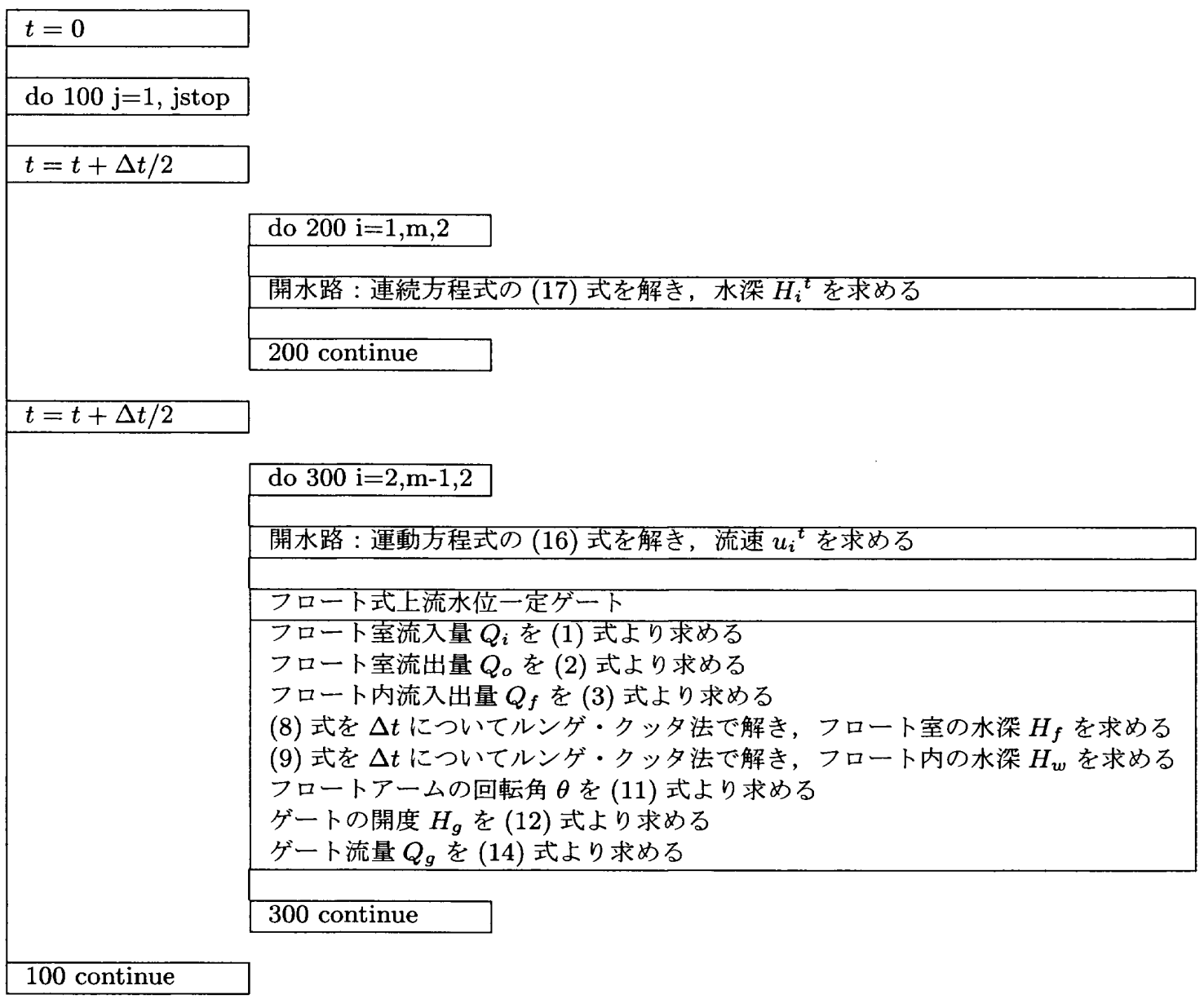

図 8: フローチャート

\section{2 実験条件}

水理実験は, ゲートが上流側からの流量変動に対して, 設定水深を所定の精度で保持しつつ, 速やかに対忘で きるがどうかを検証するのが目的である．そこで，愛 知池から設定流量を放流し, 八幡チェック上流の東浦 揚水機場の揚水量を変化させて, ゲート通過流量を変 更する方法で行った. さらに，ゲート稼働中にゲート を一部閉鎖する場合とゲートの設定水深を変更する場 合についても検証を行った.

実験設備を図 9 に示すが，ゲートの上流水位とゲー 卜開度については, 量水表と開度計をビデオで撮影し, 映像データを数值化した。 また，下流水位は量水表を 目視して記録した. 実験条件の時間的経過については, 表 4 に示すとおりである.

\section{3 実験結果}

図 10 に放流量, ポンプ揚水量, 稼働ゲート数, 上流 設定水梁の実験条件とグート上下流の水深とグート開 度の計測值の時間変化を示す.ゲート地点の流量は, 東浦揚水機場のポンプが起動停止するたびに増減を繰 り返すが, ゲート下流水深はこの流量の増減に対応し て上下動している. 一方, 上流水深は $0 \sim 2.5 \mathrm{hr}$ では設 定水深 $1.9 \mathrm{~m}$ 近傍に制御されており, 設定水深を $2.5 \mathrm{hr}$ 以降で $2.0 \mathrm{~m}$ に増加し, その後 $1.8 \mathrm{~m}$ に減少させた場
合でも上流水深は速やかに移行している.

ゲート開度は，実験条件の変更に合わせて追従して 変化しており，条件変更時に開閉を繰り返すようなハ ンチング現象は生じていない，従って，現地水理実験 の結果からは, 間接型フロート式上流水位一定ゲート は, 実際の運用時における様々な水理条件の変化に十 分対応でき, かつ所定の水位制御精度が得られる機能 を有していると考えられる.

\section{7 シミュレーションによる再現検討}

\section{1 解析モデル}

解析モデルの概要は図 11 に示すが，解析の対象とす る区間は，上流端を大堀暗渠の始点，下流端を八幡卜 ンネルの出口と設定した. 八幡チェックの下流には桜 鐘チェックがあり, ゲートで上流に堰上げているので, 桜鐘チェックの設定水位 EL $32.420 \mathrm{~m}$ を静止水位とす るために, 下流端には標高 EL32.50m の位置に仮想の 余水吐を設置し, さらに越流水深を小さく抑えるため に，延長を $50 \mathrm{~m}$ とした.

境界条件としては，上流端を流量境界として放流量 を与え，下流端は桜鐘チェックが全閉され，行き止ま りの状態になっているとして取り扱い，上流からの流 量が到達して末端水路水位が仮想余水吐の天端を越え る場合は, 越流水媣に相当する流量が余水吐からの横 
表 3: 東浦揚水機場・八幡チェックゲートの諸元

\begin{tabular}{ccc|ccc}
\hline \multicolumn{3}{c|}{ 東浦揚水機場 } & \multicolumn{3}{c}{ 八幡チェックゲート } \\
\hline ポンプ & 諸元 & 単位 & ゲート & 諸元 & 単位 \\
\hline \hline 台数 & 2 & 台 & 台数 & 2 & 台 \\
口径 & 800 & $\mathrm{~mm}$ & 幅 & 3.50 & $\mathrm{~m}$ \\
機種 & 渦巻 & & 高さ & 2.40 & $\mathrm{~m}$ \\
容量 & \multirow{2}{*}{1.20} & $\mathrm{~m}^{3} / \mathrm{s}$ & 形式 & 自動水位調節水門扉 & \\
& & & 敷高 & EL 31.30m & \\
& & & 設定水深 & $1.80 \sim 2.20$ & $\mathrm{~m}$ \\
& & & 計画流量 & 15.0 & $\mathrm{~m}^{3} / \mathrm{s}$ \\
\hline
\end{tabular}

表 4: 放流量・ポンプ揚水量・設定水深・稼働数の変化パターン

\begin{tabular}{|c|c|c|c|c|}
\hline 時間 & 上流放流量 & 東浦揚水量 & ゲート設定水深 & 稼働ゲート数 \\
\hline 時間：分 & $\mathrm{m}^{3} / \mathrm{s}$ & $\mathrm{m}^{3} / \mathrm{s}$ & $\mathrm{m}$ & 台 \\
\hline $0: 00 \sim 0: 30$ & \multirow{11}{*}{7.544} & 0.0 & \multirow{8}{*}{1.9} & \multirow{3}{*}{2} \\
\hline $0: 30 \sim 1: 00$ & & 2.4 & & \\
\hline $1: 00 \sim 1: 30$ & & \multirow[t]{2}{*}{1.2} & & \\
\hline $1: 30 \sim 1: 40$ & & & & \multirow{4}{*}{1} \\
\hline $1: 40 \sim 2: 00$ & & 0.0 & & \\
\hline $2: 00 \sim 2: 30$ & & 2.4 & & \\
\hline $2: 30 \sim 2: 35$ & & \multirow{3}{*}{1.2} & & \\
\hline $2: 35 \sim 2: 40$ & & & & \multirow{4}{*}{2} \\
\hline $2: 40 \sim 2: 55$ & & & 2.0 & \\
\hline $2: 55 \sim 3: 00$ & & \multirow[t]{2}{*}{1.8} & 1.8 & \\
\hline $3: 00 \sim 3: 30$ & & & 1.9 & \\
\hline
\end{tabular}

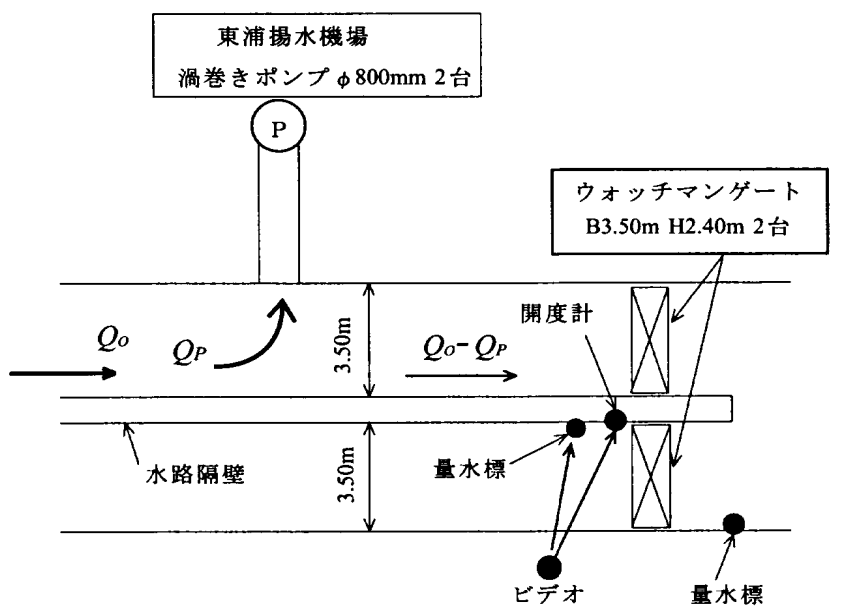

図 9: 水理実験設備

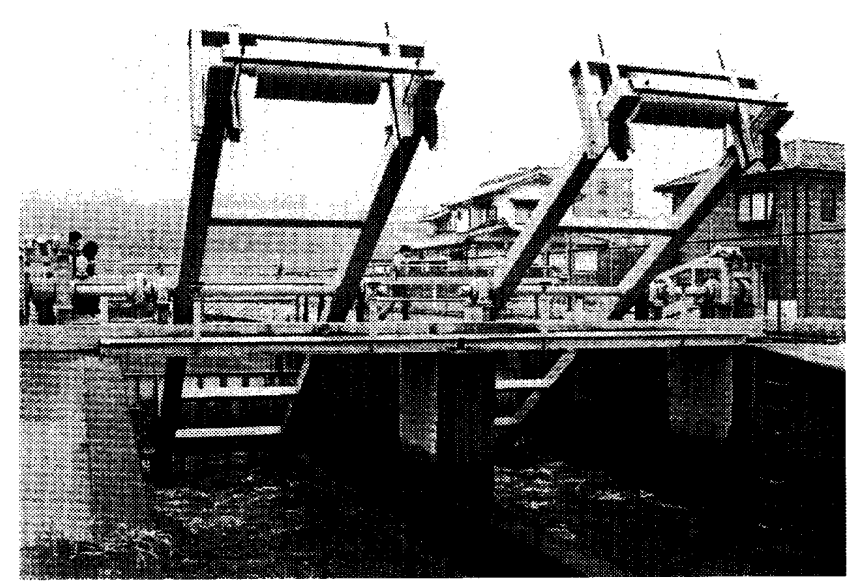

写真 1: 八幡チェックゲート
流出量として，系外に放流されるモデルとした。また， 東浦揚水機場は，八幡チェックの直上流において，ポ ンプによる揚水量を分水量として系内から取り出すモ デルとした.

水路の断面形状は, 暗渠は 2 連断面, 開水路は溺れ 隔壁を設置した 2 連断面, トンネルは $2 \mathrm{R}$ 標準馬蹄形 断面であり，寸法諸元は図中に示している. 水路断面 としては，写真 2 に示すような通常時において中間隔 壁が水面に溺れた状態の 2 連水路を考慮しており,さ
らに写真 1 に示す 2 台のゲートは同じ動きをするもの と仮定して，1台のグートに 2 台分の幅を与えている. なお, 距離差分 $\Delta x$ は $10 \mathrm{~m}$, 時間差分 $\Delta t$ は $0.1 \mathrm{~s}$ と設 定した.

\section{2 解析ケース}

解析ケースは, 間接型フロート式上流水位一定ゲート の現地水理実験の結果を数值モデルを用いて再現する ケース $\mathrm{A}$ と間接型フロート式ゲートの制御方法の特 


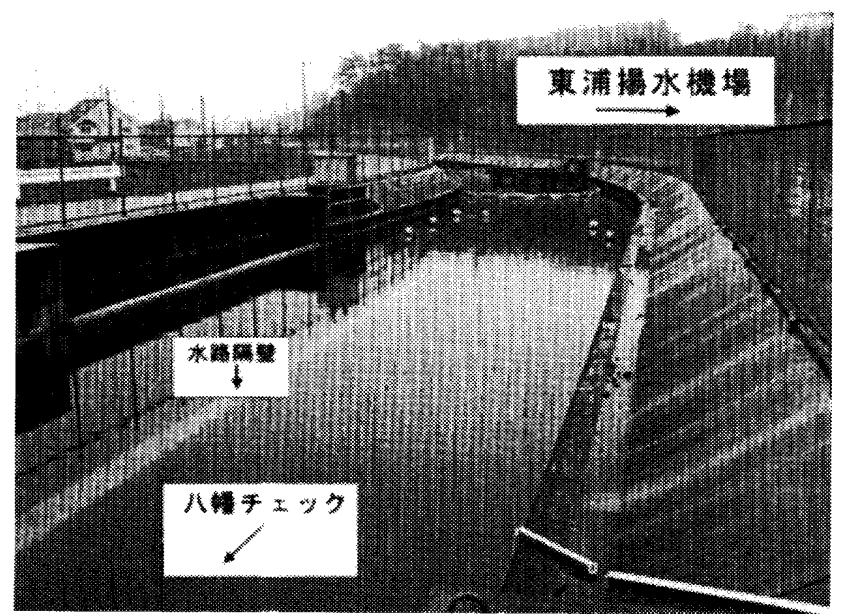

写真 2: 八幡チェック上流開水路

徴であるフロート内へ水を入れる場合の効果を確認す るために, フロート内へ水を入れない場合のケース B の 2 ケースを設定した．表 5 にケース A， B における ゲート諸元を示す。

\section{3 フロート内人水を入れる場合}

図 12 に流量, 稼働ゲート数, 上流設定水位の実験条 件とゲート上下流の水深とゲート開度の実測値と計算 值の時間変化を比較して示す.

\subsection{1 上流水深}

ゲートの上流水深については，実測値と計算值はほ ぼ一致しており，東浦揚水機場のポンプ運転あるいは ゲート移動台数の変更によって変化することなく, 設 定した水深に制御されている。 また, $2.5 \mathrm{hr}$ 以降で設 定水深を $2.0 \mathrm{~m}$ と $1.8 \mathrm{~m}$ に変更する場合では, 計算水 深の值は実測值とよい一致を示しているが，計算水深 の変化傾向は実測值より急となっている.

\subsection{2 下流水深}

ゲートの下流水深についても，実測值と計算値はよい 一致を示している. しかし， $2.5 \mathrm{hr}$ 以降で上流設定水 深を変更する場合に, 計算值の方が一時的な変動幅が 大きくなっているが，これは実験では注水堰の高さを 手動のハンドルで変更するのに対して, 計算では瞬時 に変更したために生じた違いであると考えられる.

\subsection{3 ゲート開度}

ゲート開度については, ゲートが 2 台稼働し, 設定水 媣を変更しない $1.5 \mathrm{hr}$ までは, 実測值と計算値はよく 一致している，その後，稼働ゲートを 1 台に減らす場 合と上流設定水深を $1.8 \mathrm{~m}$ に変更する場合に, 計算值 が実測值より大きくなっている.

計算は 1 次元流であるので隔壁が水没した状況の 2 連水路断面について, 平均的な流速と水深を用いて流 量を求めており，2 連水路の流れに直角方向の水の動 きはないものと仮定し, 上流からの流量がすべて稼動 ゲート側に到達するとしている．従って， $1.5 \mathrm{hr}$ にお いてゲートを 1 台閉鎖する状況は，2 台分のゲート幅 を 1 台分に減少させているため, 同一流量が流下して

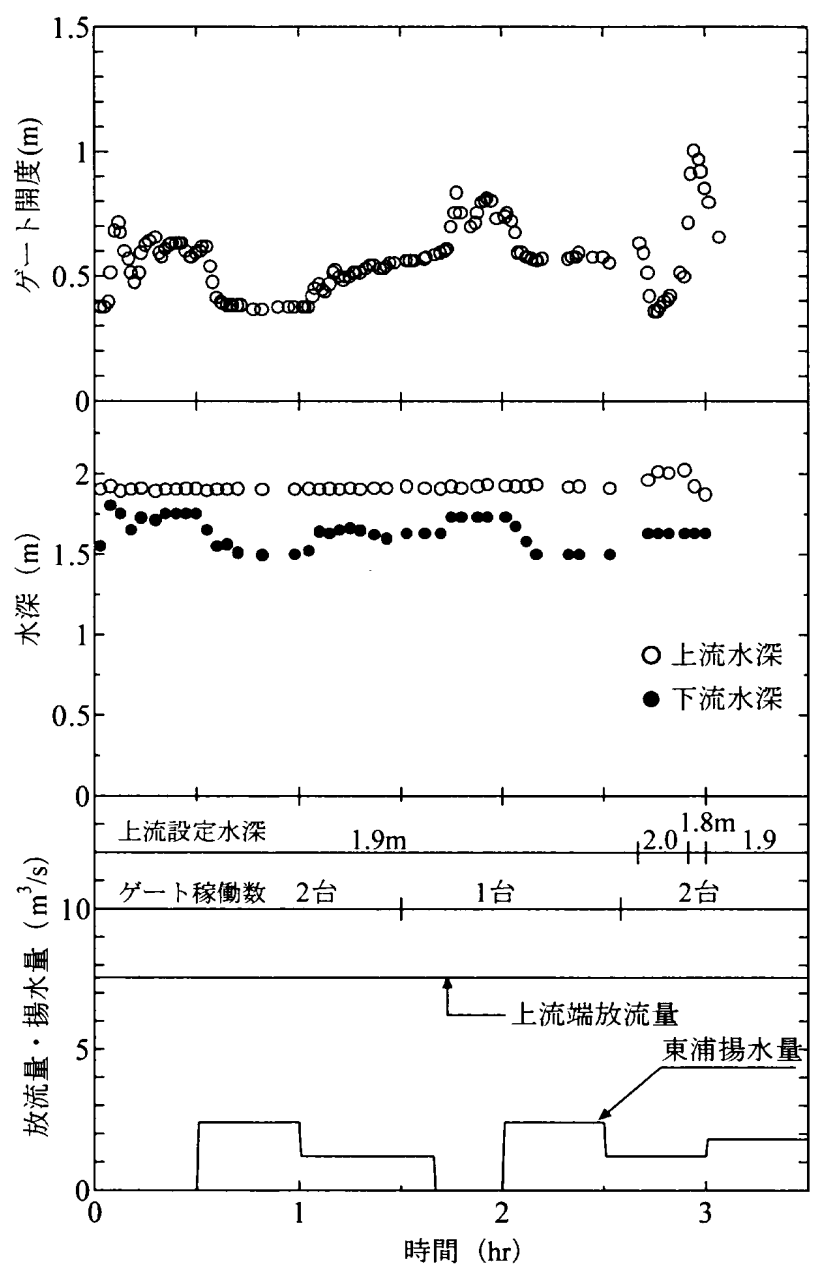

図 10: 現地水理実験結果

きた場合は，ゲート開度が約 2 倍になる結果となって いる.

現地実験では，稼働中のゲート 2 台の中の 1 台を 閉鎖したため, 2 連水路の片側の水路の流れが閉鎖し たゲートで堰き止められて水位が上昇し，ゲートが稼 働している隣の水路へ流入してきて，稼働ゲートの直 上流で渦を巻くような状況であった．実験では 2 台の ゲートの直上流部では 3 次元的な流れの形態を示して いるので, 計算のようにゲート開度の増加が顕著に現 れない結果となったと考えられる。

また, $2.5 \mathrm{hr}$ 以降では上流設定水深を $2.0 \mathrm{~m}$ から $1.8 \mathrm{~m}$ に急激に変更しているため，ゲート開度が一時的に大 きくなる傾向にある.これは上流設定水深を低く設定 することにより，ゲート上下流での水位差が小さくな るので，ゲート開度が大きくなったものと考えられる. これについても，計算值が実測值を上回る結果が得ら れているが，上流設定水深を下げたため，隔壁をはさ んだ両側の水路の水の行き来が弱くなって, ゲート通 過流量に影響を与えたのでないかと推察される。

\subsection{4 フロートの作動機構}

間接型フロート式上流水位一定ゲートの特徵は，フ ロート内へ水を入れることにより，所定の喫水差が確 


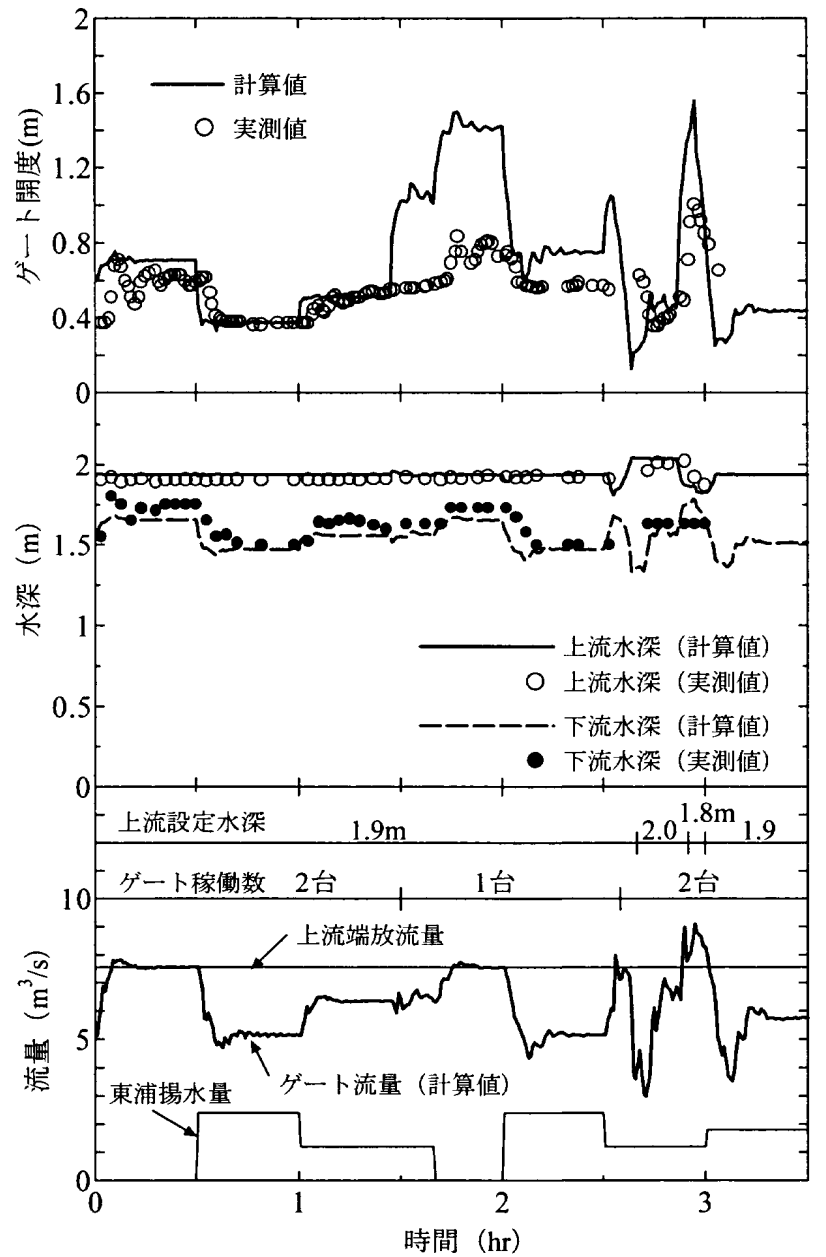

図 12: 水深・流量変化図（ケース A）

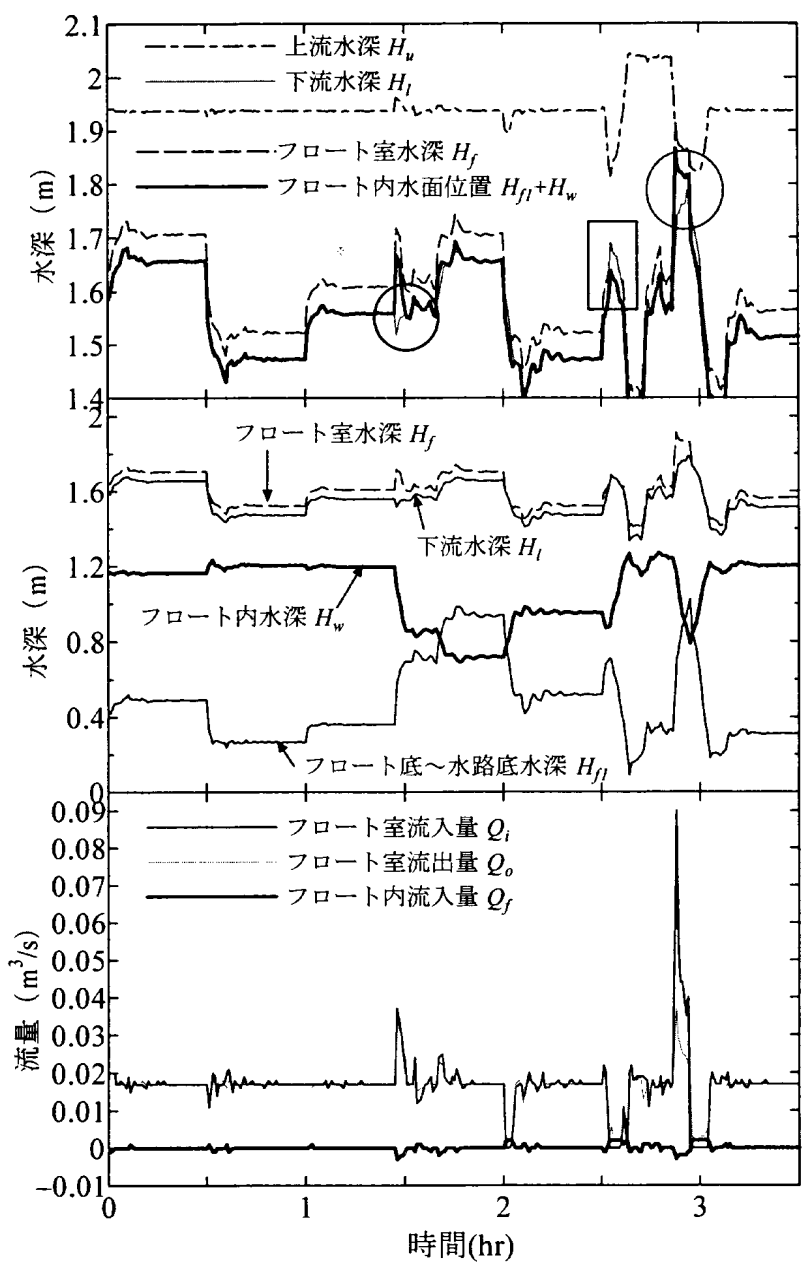

図 13: フロート室水深・流量変化図（ケース A）
保できれば，フロートは任意の位置に保持することが できるので, フロート室の小さな水深変化でも, 大き なフロート移動量を得ることができる点にある. 図 13 にケース A のフロート内外の水深とフロート室・内人 の流入出量を示し，流量が増減する場合のゲートの作 動機構を数值モデルのプロセスで以下に記述する。ま た, 流量が減少する場合は, 増加する場合と逆のプロ セスをたどる. 図 13 の上段に水深の時系列変化を示 しているが，この中に流量が増加する場合を○印で， 減少する場合を口印で示している。

1. 流量が増加する場合は，上流水面が上昇し，フロー 卜室への流入量が増加して，フロート室の水深が 増加する.

2. フロート室水深の増加により, フロート室からの流 出量が増加する。

3. 数值モデルでは, 喫水差を保持するためにフロー 卜内の水面位置を上昇させ，一時的にフロート内 からの流出が発生する.

4. フロート内の水深が低下することにより，フロート 底と水路底の間の水深が増加し, フロートが上昇 する。
5. フロートが上昇することにより, ゲート開度が増加 して, 通過流量が増加する.

6. ゲート上流水面が低下し，ゲート下流水面は上昇 する.

7. フロート室への流入出量は少し減少し, やがて均 衡して, ゲート開度は安定する。

\section{4 フロート内人水を入れない場合}

フロート内へ水を入れない場合は，喫水差がフロート 室の水面とフロート底の差になるため, フロートの位 置は，フロート室の水深に対して一力所しか選択でき ない. そのため, 以下に示すような現象を生じる。

1. ゲートの開度がフロート室の水深に連動する.

2. 静水時においてゲートが全閉するために，大きな 喫水差が必要なためフロートが大きくなる，喫水 差の設定が不適切だと, ゲートが閉まらない状況 が発生する。

3. ゲート上下流の水位差が小さくなった場合, 所定 の流量を流下させるためには, 喫水差の大きなフ ロートと短いフロートアームを用いて，大きなゲー 卜開度を得なければならない。 


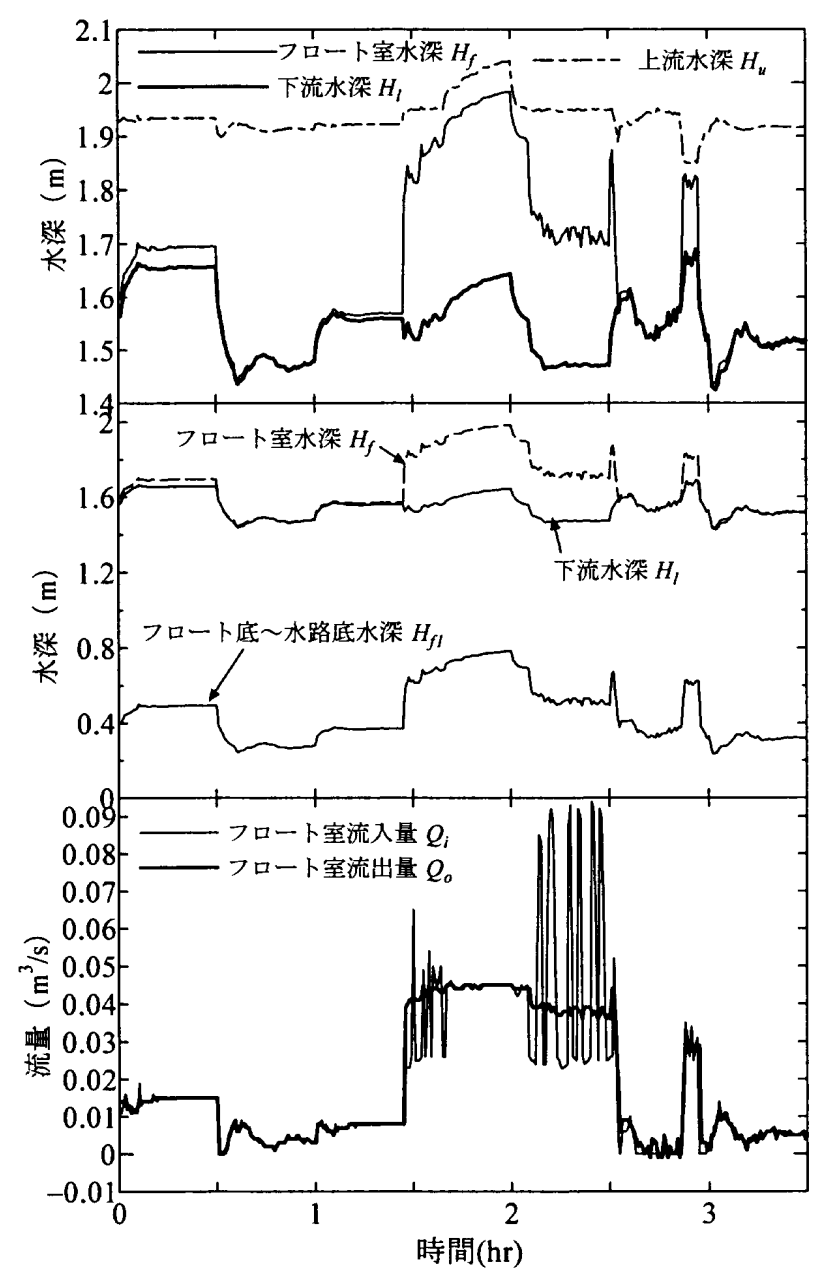

図 14: フロート室水深・流量変化図（ケース B）

4. フロート室の水深は, 水槽 $\mathrm{A}, \mathrm{B}$ からの流出入量 のみに依存するため, 注水堰と流出オリフィスの 規模を適切に設定する必要があるが，すべての流 量範囲で満足する選択はできない。

図 14 にフロート内人水を入れないケース B のフロー 卜室の水深とフロート室への流入出量を示した。また, 図 15 にフロート内人水を入れるケース $\mathrm{A}$ とケース $\mathrm{B}$ のゲート開度，ゲート上下流の水深およびゲート流量 を比較して示した。

東浦揚水機場のポンプ揚水量のみが変動する $1.5 \mathrm{hr}$ までは，ケース B の上流水位の制御精度がケース $\mathrm{A}$ に比べて僅かに悪くなる結果となっているが，フロー 卜室の水深, ゲート開度, ゲート流量等は両ケースで は大きな違いはない。

稼働ゲートが 2 台から 1 台に減少し，ポンプ揚水が 停止する $1.5 \mathrm{hr}$ 付近で，ゲート 1 台当たりの流量が増 加している．そのため，ゲート上流水深が上昇し，フ ロート室への流入が増加して, フロート室の水深が上 昇する.

1〜 $1.5 \mathrm{hr}$ で上流水深が上昇すると, 注水堰の越流 水深が大きくなり，フロート室との間で一時的にオリ フィス流となるので, 流況が完全越流とオリフィス流

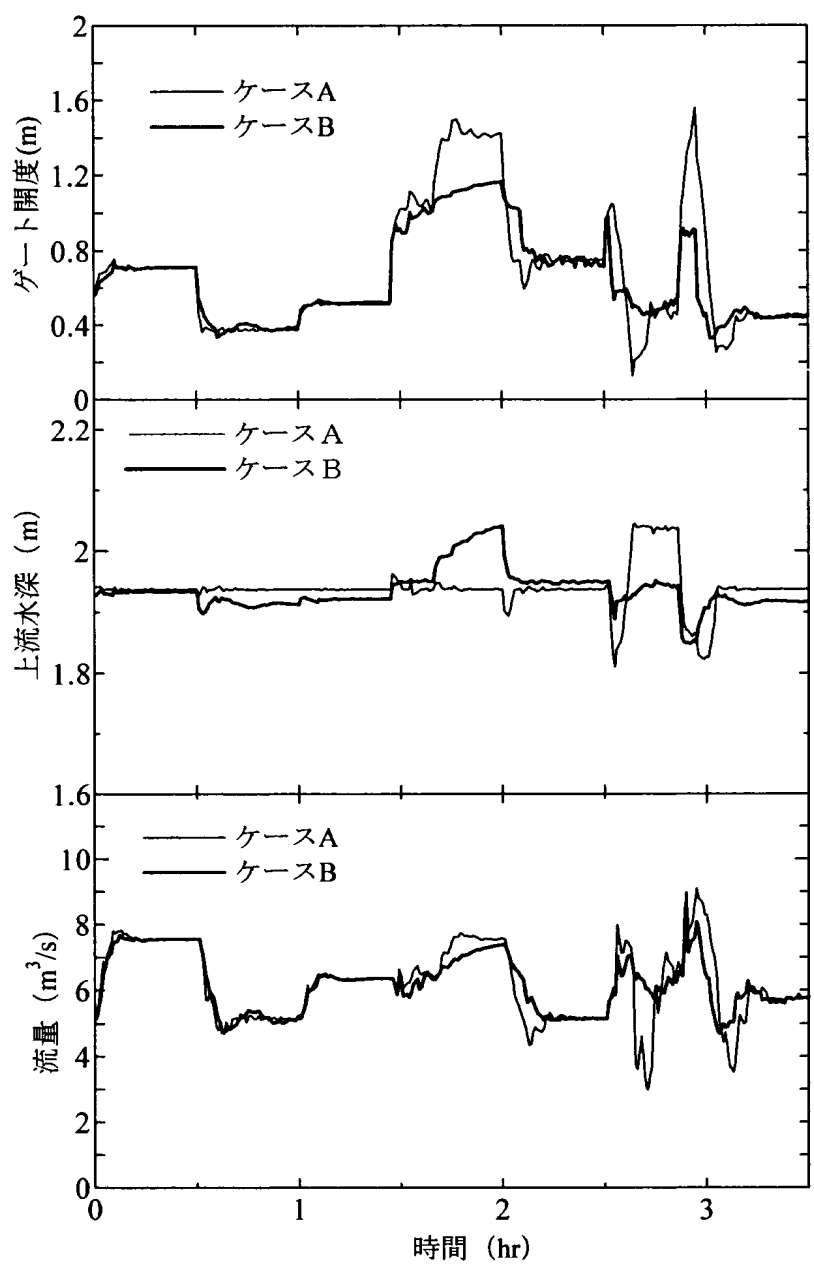

図 15: 流量・ゲート開度変化図（ケース A・B）

の閒を行き来する不安定な状況となり, 流入量の増減 を生じる．さらに，1.5〜 $2 \mathrm{hr}$ でゲート上下流の水位 差が小さくなり, 流入量と流出量が釣り合う位置まで フロート室の水深が上昇し, 流況は一旦安定する. そ の後, 2 2.5hr で下流水深が低下し, 完全越流とオリ フィス流が交互に現れる不安定な流況が発生する.

$2.5 \mathrm{hr}$ 以降に上流制御水深を変更しているが，ケー ス B ではゲート上流水深が設定水深を逸脱し，ゲート 開度とゲート流量はケース $\mathrm{A}$ に比べて大きく変動し ており，流況の安定性を欠いている。

フロート内へ水を入れない場合は, 設定条件の範囲 内での運用には制御精度の若干の低下以外の大きな支 障は認められないが, 上流制御水深の変更, 稼働ゲー 卜数の変更など運用状況が設定条件から逸脱する場合 は，所定の水位制御は期待できないと考えられる.

\section{8 おわりに}

間接型フロート式上流水位一定ゲートは, 現地水理実 験の結果からは，実際の運用時において上流水位につ いて十分な安定性と制御精度が得られる。このゲート ではフロート内へ水を入れることが機構上の特徵と なっているが, 運用状況が当初の設定条件から変更さ れる場合においても，この機構により上流水位が所定 
の水位に制御される.

間接型フロート式上流水位一定グートの作動機構に ついて，数值モデルにより実測值を再現したところ， ゲート上下流の水深については計算值は実測值を十分 に近似できると考えられる。なお，ゲート開度につい ては通常の運用をする限りにおいては, 実測值と計算 值は一致しているが，隔壁を有する 2 連水路の複雑な 水理状況が影響するような特別な状況下において，実 測値と計算值が一致しない場合がある。

これまでは, フロート式上流水位一定ゲートを連続 して設置した一貫した開水路システムの構築を目指 す場合に,アミルゲートでは愛知用水における設置条 件や水理環境に制約を受ける面があったが，間接型フ ロート式上流水位一定ゲートを導入することにより，
その実現性が増すものと考える，今後は，ゲートを連 続して設置した場合の安定性について, 現地実験と数 值実験の両面から検討を加える必要がある.

\section{引用文献}

[1] 白石英彦 (1969) : 長方形断面水路における不定流解析, 農林研究計算センター報告, A4, pp.217-225.

[2] 白石英彦・中道 宏・岩崎和己 (1972) : 水位調節ゲー 卜を含む用水系における非定常シミュレーション手法, 農土試技報, F7, pp.21-29.

[3] 土木学会 (1971): 水理公式集, pp.276-277.

[4] 農林水産省構造改善局 (2001a)：土地改良事業計画設 計基準設計「水路工」技術書, pp.559-560.

[5] 農林水産省構造改善局 (2001b)：土地改良事業計画設 計基準設計「水路工」技術書, pp.560-561.

(この論文に対する公開の質疑または討議は2003年6月 30日まで受付けます。 